\title{
Management of Anthracnose in Common Bean by Foliar Sprays of Potassium Silicate, Sodium Molybdate, and Fungicide
}

\author{
L. R. Polanco, F. A. Rodrigues, and E. N. Moreira, Viçosa Federal University, Department of Plant Pathology, Laboratory of Host- \\ Parasite Interaction, Viçosa, MG, 36570-000, Brazil; H. S. S. Duarte, Paraná Federal University, Plant Protection Department, SCA- \\ DFF, Curitiba, Paraná State, 80035-050, Brazil; I. S. Cacique and L. A. Valente, Viçosa Federal University, Department of Plant \\ Pathology, Laboratory of Host-Parasite Interaction, Viçosa, MG, 36570-000, Brazil; R. F. Vieira and T. J. Paula Júnior, Company of \\ Farming Research of Minas Gerais (EPAMIG), Vila Gianetti, 47, Viçosa, MG, 36570-000, Brazil; and F. X. R. Vale, Viçosa Federal \\ University, Department of Plant Pathology, Viçosa, MG, 36570-000, Brazil
}

\begin{abstract}
Polanco, L. R., Rodrigues, F. A., Moreira, E. N., Duarte, H. S. S., Cacique, I. S., Valente, L. A., Vieira, R. F., Paula Júnior, T. J., and Vale, F. X. R. 2014. Management of anthracnose in common bean by foliar sprays of potassium silicate, sodium molybdate, and fungicide. Plant Dis. 98:84-89.

This study aimed to determine whether foliar sprays of potassium silicate $(\mathrm{KSi})$, sodium molybdate $(\mathrm{NaMo})$, or a combination of both $(\mathrm{KSi}+\mathrm{NaMo}$ ), with or without the fungicide azoxystrobin (Azox), could reduce anthracnose symptoms and, consequently increase yield. Two two-by-four factorial experiments, consisting of untreated or fungicide treated, as well as sprays of $\mathrm{KSi}, \mathrm{NaMo}, \mathrm{KSi}+\mathrm{NaMo}$, and no spray (control), were arranged in a randomized block design with three replications. Treatments were as follows: treatment 1, KSi spray; treatment 2, NaMo spray; treatment 3, KSi + NaMo spray; treatment 4, Azox spray; treatment 5, Azox $+\mathrm{KSi}$ spray; treatment 6 , Azox $+\mathrm{NaMo}$ spray, treatment 7, Azox + KSi + NaMo spray; and treatment 8, control (no KSi, NaMo, or Azox). The KSi, NaMo, and Azox treatments were sprayed at the rates of $35 \mathrm{~g} / \mathrm{liter}, 90 \mathrm{~g} / \mathrm{ha}$, and $120 \mathrm{~g}$ a.i./ha, respectively. The KSi was applied at 20, 27, 40, and 55 days after sowing (das). The NaMo was sprayed only at 27 das whereas the fungicide

was sprayed at 27, 40, and 55 das. Plants were inoculated with Colletotrichum lindemuthianum at 23 das. Azox reduced the mean area under disease progress curve (AUDPC) by 63\% and mean yield was increased by $150 \%$. Similarly, the mean AUDPC was reduced by 29,14 , and $41 \%$ with $\mathrm{KSi}, \mathrm{NaMo}$, and $\mathrm{KSi}+\mathrm{NaMo}$ sprays, respectively, while mean yield increased by 13,20 , and $47 \%$, with $\mathrm{KSi}, \mathrm{NaMo}$, or $\mathrm{KSi}+$ NaMo sprays, respectively. The variables leaf area index (LAI), leaf area index duration (LAD), healthy leaf area duration (HAD), and radiation intercepted (RI) were not affected by $\mathrm{KSi}$ spray. The values for the variables LAI, healthy leaf area index (HLAI), LAD, HAD, RI, intercepted radiation of the healthy leaf area, and healthy leaf area absorption were significantly increased as a result of NaMo spray. The results of the present study support the novel possibility of using a foliar spray of $\mathrm{KSi}$ in association with NaMo to decrease anthracnose symptoms in bean plants and, consequently, achieve greater yield.
\end{abstract}

Anthracnose, caused by the hemibiotrophic fungus Colletotrichum lindemuthianum (Sacc. \& Magnus), is one of the most important diseases of common bean (Phaseolus vulgaris L.) in Brazil and worldwide because of its capacity to cause great yield losses. Under environmental conditions favorable for disease progress such as high relative humidity and temperature between 18 and $20^{\circ} \mathrm{C}$, yield can be drastically reduced. The disease affects the leaves, petioles, pods, and seed of bean plants (37).

Considering the losses caused by anthracnose on bean yield, it is necessary to implement adequate disease management strategies. The analysis developed by Waggoner and Berger (39) showed that yield and plant dry weight are most often a function of the photosynthetically active area (healthy) of the plant and not the diseased area, thus evoking the concepts of healthy leaf area index (HLAI), healthy leaf area duration (HAD), and healthy leaf area absorption (HAA). Johnson (16) refined this concept by suggesting that the pathogens affect both the radiation intercepted (RI) and absorbed due to defoliation, showing the importance of the infection process of any foliar pathogen on radiation use efficiency (RUE). The applicability of the concepts of such integral variables as leaf area index (LAI), HLAI, HAD, HAA, intercepted radiation of the healthy leaf area (HRI), and others has been reported for many host-pathogen interactions $(1,2,20,26)$.

Corresponding author: F. A. Rodrigues, E-mail: fabricio@ufv.br

Accepted for publication 21 July 2013.

http://dx.doi.org/10.1094/PDIS-03-13-0251-RE

(c) 2014 The American Phytopathological Society
Different control strategies can be employed by growers for integrated anthracnose management. Resistant cultivars are used more often than fungicide sprays (37). However, the presence of various physiological races of the pathogen is a great obstacle for obtaining new resistant cultivars to anthracnose (29). Fungicide sprays are effective in decreasing anthracnose severity and increasing bean yield (27) but their use is limited due to the risk of emergence of resistant populations of the pathogen (37).

Although silicon $(\mathrm{Si})$ is not considered to be essential for plants (8), there are well-recognized positive benefits that this element brings to many plants species such as increased drought tolerance; greater tolerance of aluminum, iron, and manganese toxicity; as well as reduced pathogen infection $(4,9,18,19,30)$. Among the defense mechanisms enhanced by $\mathrm{Si}$ is the formation of a physical barrier below the cuticle after monosilicic acid polymerization as well as an increase in the concentrations of total soluble phenolics and phytoalexins and higher activity of defense enzymes $(18,33)$. In dicotyledonous plants such as cucumber, melon, and pumpkin, foliar applications of potassium silicate $(\mathrm{KSi})$ reduced the number of colonies of Sphaerotheca fuliginea (23). On bean, foliar application of sodium silicate decreased the area under anthracnose progress curve by $62 \%$ (25). Foliar application of KSi at rates of 0 to $60 \mathrm{~g} /$ liter increased $\mathrm{Si}$ concentration in bean leaves by $58 \%$. The highest KSi rate reduced angular leaf spot severity on common bean by 42 and $30 \%$ and defoliation by 17 and $33 \%$ at $\mathrm{pH} 5.5$ and 10.5 , respectively, compared with the untreated control. Yield also increased by 30 and $43 \%$ as KSi rates increased from 0 to $60 \mathrm{~g} / \mathrm{liter}$ with pH 5.5 and 10.5 , respectively (32).

Molybdenum (Mo) is an essential micronutrient for plants due to its participation as a catalytic metal during the redox reactions of some enzymes in leaf tissues (36). The enzymes nitrate reductase (NR), sulfite oxidase, xanthine dehydrogenase, and aldehyde oxi- 
dase are all Mo dependent (22). The exact role of Mo in resistance to diseases has yet to be determined; however, it is known that a decrease in the Mo concentration in the soil solution can decrease host resistance to diseases by affecting the production of NR, an enzyme that contains two Mo atoms, which is required to convert nitrates into proteins (17). Reduction in the activity of Mo-dependent enzymes affects plant growth, particularly with regard to nitrogen metabolism, and also the synthesis of abscisic acid and indole3-butyric acid (17). Mo has been reported to reduce the symptoms of Verticillium wilt on tomato plants $(7,24)$ and, according to Halsall (13), Mo inhibits the production of zoospores by Phytophthora cinnamomi and $P$. drechsleri. The population of Rotylenchulus reniformis on the roots of castor bean plants was decreased in soil amended with Mo (14). Jesus Júnior et al. (15) showed that one application of sodium molybdate (NaMo) to bean plants grown in a Mo-deficient soil at 25 days after sowing reduced angular leaf spot severity and increased the area of healthy leaves, photosynthesis, and yield. The combination of fungicide, applied once or twice, during the interval from 25 to 45 days after sowing, with NaMo at 25 days increased plant growth and reduced the angular leaf spot severity (15).

To the best of our knowledge, however, information in the literature regarding the effects of $\mathrm{Si}$ and $\mathrm{Mo}$, and the combination of these elements in association with fungicide applications, on the reduction of anthracnose progress is lacking. Therefore, this study aimed to determine whether foliar application of $\mathrm{KSi}, \mathrm{NaMo}$, or a combination of both salts, with or without a fungicide, could reduce anthracnose symptoms and, consequently, increase yield due to better plant growth.

\section{Materials and Methods}

Inoculum production. Isolate 81-538 (race 81 ) of $C$. lindemuthianum, obtained from the Bean Fungus Collection Culture from the Department of Biology, Viçosa Federal University, was used in this study. The isolate was preserved on strips of filter paper placed into glass tubes containing silica gel at $4^{\circ} \mathrm{C}$. Pieces of filter paper with fungal mycelia were transferred to petri dishes containing potato-dextrose-agar (PDA). For inoculum production, PDA plugs ( $5 \mathrm{~mm}$ in diameter) containing fungal mycelia were placed on the surface of sterilized bean pods with their bases inserted into glass tubes containing water/agar $(3 \%, \mathrm{vol} / \mathrm{vol})$. The tubes were stored in a growth chamber (MA-835/2106UR; Marconi) at $25^{\circ} \mathrm{C}$ with a photoperiod of $12 \mathrm{~h}$ of light and $12 \mathrm{~h}$ of darkness for 10 days. After acervuli were formed on pods, distilled water was added to the tubes to obtain a conidial suspension. The suspension was filtered through double cotton gauze and adjusted to a concentration of 1.2 $\times 10^{6}$ conidia/ml using a Neubauer-counting chamber. Gelatin $1 \%$ (wt $\mathrm{vol}^{-1}$ ) was added to the suspension to facilitate the adhesion of conidia to the leaf surface.

Plant growth, treatments, and inoculation with $C$. lindemuthianum. Two field experiments were conducted in an experimental area at Viçosa Federal University in Viçosa, Brazil, which is located in the southeastern region of Minas Gerais State at $20^{\circ} 44^{\prime} 44^{\prime \prime} \mathrm{S}, 42^{\circ} 50^{\prime} 59^{\prime \prime} \mathrm{W}$, and $661 \mathrm{~m}$ above sea level. The first experiment was performed from March to May 2009 and the second from September to December 2009. The chemical characteristics of the red oxisol of the experimental area were as follows: $\mathrm{pH}$ $\left(\mathrm{H}_{2} \mathrm{O}\right)$ 5.4; $\mathrm{P}, 17 \mathrm{mg} \mathrm{dm}^{-3} ; \mathrm{K}, 80 \mathrm{mg} \mathrm{dm}^{-3} ; \mathrm{Ca}^{2+}, 3.41 \mathrm{cmol} \mathrm{dm}^{-3}$; $\mathrm{Mg}^{2+}, 0.44 \mathrm{cmol} \mathrm{dm}^{-3}$; and $\mathrm{Al}^{3+}, 0.0 \mathrm{cmol} \mathrm{dm}{ }^{-3}$. The concentration of Mo in the soil was $0.2 \mathrm{mg} / \mathrm{kg}$ of soil, which is below the desirable level required by bean plants of 0.5 to $5 \mathrm{mg} / \mathrm{kg}$ of soil (12). In total, 10 plants ('Pérola', a 'Carioca' type susceptible to anthracnose) were kept per linear meter. The plots were maintained using conventional practices for bean crops, including fertilization before sowing based on the results of the soil chemical analysis. The soil was fertilized with nitrogen, $\mathrm{P}_{2} \mathrm{O}_{5}$, and $\mathrm{K}_{2} \mathrm{O}$ at 20,70 , and 40 $\mathrm{kg} / \mathrm{ha}$, respectively, and the plants received insecticidal spray, weeding, and sprinkler irrigation as needed. Each experimental plot consisted of five rows of $5 \mathrm{~m}$ in length, each spaced at $0.5 \mathrm{~m}$, corresponding to a total area of $12.5 \mathrm{~m}^{2}$. The distance between plots was $1 \mathrm{~m}$. Each experiment was a two-by-four factorial experiment arranged in a randomized block design with three replications. The first factor was azoxystrobin (Azox) or no Azox application and the second factor consisted of the applications of $\mathrm{KSi}$, $\mathrm{NaMo}, \mathrm{KSi}+\mathrm{NaMo}$, and a control (no spray). In summary, the treatments were as follows: treatment $1, \mathrm{KSi}$; treatment $2, \mathrm{NaMo}$; treatment 3, KSi + NaMo; treatment 4, Azox; treatment 5, Azox + $\mathrm{KSi}$; treatment 6, Azox + NaMo, treatment 7, Azox + KSi + NaMo; and treatment 8, control (no spray). To avoid interplot interference, only the three central rows of each plot were used for all assessments. For these three rows, plants located at $0.5 \mathrm{~m}$ from plot ends were not used in the assessments. The source of Si used to spray plants was $\mathrm{KSi}\left(26.7 \% \mathrm{SiO}_{2}\right.$ and $13.1 \% \mathrm{~K}_{2} \mathrm{O}$; FertiSil; PQ Silicas Brazil) at the rate of $35 \mathrm{~g} / \mathrm{liter}$, corresponding to $14 \mathrm{~kg} / \mathrm{ha}$. Mo was applied as NaMo (Sigma-Aldrich) at the rate of $90 \mathrm{~g} / \mathrm{ha}$. The fungicide Azox (Amistar 50 WG; Syngenta) was applied at the rate of $120 \mathrm{~g}$ a.i./ha. Treatments were applied to all five rows of each plot but timing of application varied. KSi was sprayed at 20, 27, 40, and 55 days after sowing (das), corresponding to the plant growth stages of V3, V4, R5, and R6, respectively (40). Plants were sprayed with NaMo at 27 das for maximum Mo uptake by the bean leaves, and the fungicide was applied at 27, 40, and 55 das. Treatments were applied in approximately $500 \mathrm{ml}$ of solution with a $\mathrm{CO}_{2}$ pressurized backpack sprayer at two bars $\left(3.1 \times 10^{5} \mathrm{~Pa}\right)$ with Teejet 110.03 nozzles. Plants from all rows of each plot were inoculated with a conidial suspension of $C$. lindemuthianum (approximately $500 \mathrm{ml}$ of suspension per plot) using a $\mathrm{CO}_{2}$ pressurized backpack sprayer $\left(3.1 \times 10^{5} \mathrm{~Pa}\right)$ with Teejet 110.03 nozzles at 23 das (growth stage V3).

Assessment of anthracnose severity. Anthracnose severity was assessed weekly on the leaves of plants starting at 35 das using a diagrammatic scale, with severity values of 0.1 to $24 \%$ (10). Data for severity over time were used to calculate the area under disease progress curve (AUDPC) according to Shaner and Finney (34).

Determination of grain yield. Production of shelled bean (g/plant) was determined for the plants from the three central rows of each plot, with a total area of $6 \mathrm{~m}^{2}$ and containing 120 plants. The seeds were weighed at $12 \%$ moisture content.

Determination of integral variables. LAI, expressed in $\mathrm{m}^{2} / \mathrm{m}^{2}$, was determined by multiplying the average leaf area of 20 plants by 20 , considering 20 plants $/ \mathrm{m}^{2}$. The HLAI was obtained based on the LAI and expressed in $\mathrm{m}^{2} / \mathrm{m}^{2}$ according to Waggoner and Berger (39). Leaf area index duration (LAD), expressed in days, was calculated as described by Watson (40). The HAD, expressed in days, was calculated according to Waggoner and Berger (39). The LAD was obtained through the integration of the time values of LAI and expressed in days, as defined by Watson (40). Starting at 35 das, plants from each plot were assessed weekly using destructive sampling to determine the variables described above. The leaves were passed through an area meter (LI-3100C; LI-COR Inc.) to determine leaf area prior to drying. The RI, expressed as $\mathrm{MJ} / \mathrm{m}^{2}$, was calculated according to Bergamin Filho et al. (2) using a $k$ factor of 0.7 for a bean crop (28). The HRI, as expressed in $\mathrm{MJ} / \mathrm{m}^{2}$, was obtained according to Bergamin Filho et al. (2). The $\mathrm{HAA}$, as expressed in $\mathrm{MJ} / \mathrm{m}^{2}$, for each plant was calculated according to Waggoner and Berger (39). The RUE, expressed in g/MJ, was estimated by a regression analysis between the accumulated plant dry weight $\left(\mathrm{g} / \mathrm{m}^{2}\right)$ and the sum of HAA weekly $\left(\mathrm{MJ} / \mathrm{m}^{2}\right)$, according to Sinclair and Muchow (35). Starting at 35 das, the plants were assessed weekly for these variables, without destructive sampling, using a portable open-system infrared gas analyzer (LI-6400; LI-COR Inc.).

Statistical analysis. Data for the variables evaluated in each experiment were subjected to an analysis of variance. Means for the treatment sprayed or not sprayed with Azox as well as the orthogonal contrasts (NaMo spray versus no NaMo spray, KSi spray versus no KSi spray, and NaMo spray + KSi spray versus no NaMo + KSi spray) were compared by an $F$ test using SAS (version 9.1; SAS Institute, Inc.). The effects of KSi, NaMo, KSi + NaMo, and 
no spray (control) alone or in combination with Azox on all variables studied was determined according to Tukey's test.

\section{Results}

AUDPC and grain yield. Fungicide applications reduced disease severity and resulted in greater yields in both experiments. In the first experiment, AUDPC was $67.7 \%$ lower for plants sprayed with Azox fungicide compared with nonsprayed plants (Table 1) whereas, in the second, AUDPC decreased by $58.7 \%$ with fungicide spray (Table 2). Grain yield was higher in plants sprayed with fungicide, with an increase of 148.9 and $152.2 \%$ compared with the nonsprayed plants in experiments 1 and 2, respectively (Table 1 ).
Similarly, applications of $\mathrm{KSi}, \mathrm{NaMo}$, and $\mathrm{NaMo}+\mathrm{KSi}$ reduced disease severity, although not as effectively as an application of Azox, and yields were greater than that of the untreated control. In experiment 1 , applications of $\mathrm{KSi}, \mathrm{NaMo}$, and $\mathrm{NaMo}+\mathrm{KSi}$ reduced AUDPC by $23.8,11.5$, and $32.8 \%$, respectively (Tables 3 and 4 ), while grain yield increased by $6.2,11.7$, and $46.1 \%$, respectively (Tables 4 and 5). In experiment 2, AUDPC decreased by $34.5,17.4$, and $50.9 \%$ and grain yield increased by $20.9,29.2$, and $48.7 \%$ for the plants sprayed with $\mathrm{KSi}$, NaMo, and $\mathrm{NaMo}+\mathrm{KSi}$, respectively (Tables 6 and 7).

Variables related to plant growth. Fungicide applications increased all the variables related to plant growth in both experiments. In the first experiment, the LAI, HLAI, LAD, and HAD

Table 1. Area under anthracnose progress curve (AUDPC), leaf area index (LAI, $\mathrm{m}^{2} / \mathrm{m}^{2}$ ), healthy leaf area index (HLAI, $\left.\mathrm{m}^{2} / \mathrm{m}^{2}\right)$, leaf area index duration (LAD, days), healthy leaf area duration (HAD, days), intercepted radiation of the healthy leaf area (HRI, MJ $/ \mathrm{m}^{2}$ ), healthy leaf area absorption (HAA, $\mathrm{MJ} / \mathrm{m}^{2}$ ), intercepted radiation (RI, $\mathrm{MJ} / \mathrm{m}^{2}$ ), radiation use efficiency (RUE, g/MJ), and grain yield (Yield, g/plant) on bean plants ('Pérola') inoculated with Colletotrichum lindemuthianum and sprayed $(+\mathrm{F})$ or nonsprayed $(-\mathrm{F})$ with fungicide in experiment $1^{\mathrm{z}}$

\begin{tabular}{|c|c|c|c|c|c|c|c|c|c|c|}
\hline \multirow[b]{2}{*}{ Fungicide } & \multirow[b]{2}{*}{ AUDPC } & \multicolumn{4}{|c|}{ Growth variables } & \multicolumn{4}{|c|}{ Physiological variables } & \multirow[b]{2}{*}{ Yield } \\
\hline & & LAI & HLAI & LAD & HAD & HRI & HAA & RI & RUE & \\
\hline$\overline{-F}$ & 326.17 & 2.01 & 1.92 & 88.76 & 85.00 & 9.53 & 414.79 & 9.71 & 0.21 & 7.27 \\
\hline$+\mathrm{F}$ & 105.54 & 2.20 & 2.17 & 97.28 & 95.69 & 10.07 & 437.23 & 10.13 & 0.49 & 18.1 \\
\hline MS & $292,061.16^{*}$ & $0.21 *$ & $0.37 *$ & $435.71 *$ & $685.97 *$ & $1.75 *$ & $3,019.30^{*}$ & $1.058 *$ & $0.487 *$ & $101,964.38 *$ \\
\hline CV (\%) & 14.15 & 7.81 & 7.78 & 7.38 & 7.46 & 3.01 & 2.76 & 2.92 & 3.34 & 3.38 \\
\hline
\end{tabular}

${ }^{\mathrm{z}}$ Asterisk $(*)$ indicates significant $(P=0.05)$ by $F$ test. $\mathrm{MS}=$ mean square and $\mathrm{CV}=$ coefficient of variation.

Table 2. Area under anthracnose progress curve (AUDPC), leaf area index (LAI, $\mathrm{m}^{2} / \mathrm{m}^{2}$ ), healthy leaf area index $\left(\mathrm{HLAI}, \mathrm{m}^{2} / \mathrm{m}^{2}\right)$, leaf area index duration (LAD, days), healthy leaf area duration (HAD, days), intercepted radiation of the healthy leaf area (HRI, MJ $/ \mathrm{m}^{2}$ ), healthy leaf area absorption (HAA, $\mathrm{MJ} / \mathrm{m}^{2}$ ), intercepted radiation ( $\mathrm{RI}, \mathrm{MJ} / \mathrm{m}^{2}$ ), radiation use efficiency (RUE, g/MJ), and grain yield (Yield, g/plant) on common bean plants ('Pérola') inoculated with Colletotrichum lindemuthianum and sprayed (+F) or nonsprayed $(-\mathrm{F})$ with fungicide in experiment $2^{\mathrm{z}}$

\begin{tabular}{|c|c|c|c|c|c|c|c|c|c|c|}
\hline \multirow[b]{2}{*}{ Fungicide } & \multirow[b]{2}{*}{ AUDPC } & \multicolumn{4}{|c|}{ Growth variables } & \multicolumn{4}{|c|}{ Physiological variables } & \multirow[b]{2}{*}{ Yield } \\
\hline & & LAI & HLAI & LAD & HAD & HRI & HАA & RI & RUE & \\
\hline$-\mathrm{F}$ & 53.50 & 2.32 & 2.28 & 64.01 & 62.75 & 17.66 & 450.14 & 16.68 & 0.18 & 6.96 \\
\hline$+\mathrm{F}$ & 22.11 & 2.51 & 2.48 & 68.82 & 68.12 & 18.42 & 467.56 & 17.36 & 0.45 & 17.73 \\
\hline MS & $5,911.99 *$ & $0.19 *$ & $0.25 *$ & $138.52^{*}$ & $172.96 *$ & $3.41 *$ & $1,820.56^{*}$ & $2.82 *$ & $0.43 *$ & $695.31 *$ \\
\hline $\mathrm{CV}(\%)$ & 12.96 & 4.97 & 4.70 & 5.30 & 5.20 & 3.39 & 2.80 & 3.60 & 6.47 & 5.40 \\
\hline
\end{tabular}

${ }^{\mathrm{z}}$ Asterisk $(*)$ indicates significant at $P=0.05$ by $F$ test. $\mathrm{MS}=$ mean square and $\mathrm{CV}=$ coefficient of variation.

Table 3. Effects of potassium silicate (KSi), sodium molybdate ( $\mathrm{NaMo}), \mathrm{KSi}+\mathrm{NaMo}$, and no spray (control) applied to bean foliage alone or in combination with fungicide $\left(-\mathrm{F}\right.$ and $+\mathrm{F}$, respectively) on the area under anthracnose progress curve (AUDPC) and on the growth variables leaf area index $\left(\mathrm{LAI}, \mathrm{m}^{2} / \mathrm{m}^{2}\right)$, healthy leaf area index (HLAI, $\mathrm{m}^{2} / \mathrm{m}^{2}$ ), leaf area index duration (LAD, days), and healthy leaf area duration (HAD, days) in experiment $1^{\mathrm{z}}$

\begin{tabular}{|c|c|c|c|c|c|c|c|c|c|c|}
\hline \multirow[b]{3}{*}{ Treatments } & & & \multicolumn{8}{|c|}{ Growth variables } \\
\hline & \multicolumn{2}{|c|}{ AUDPC } & \multicolumn{2}{|c|}{ LAI } & \multicolumn{2}{|c|}{ HLAI } & \multicolumn{2}{|c|}{ LAD } & \multicolumn{2}{|c|}{ HAD } \\
\hline & $-\mathbf{F}$ & $+\mathbf{F}$ & $-\mathbf{F}$ & $+\mathbf{F}$ & $-\mathbf{F}$ & $+\mathbf{F}$ & $-\mathbf{F}$ & $+\mathbf{F}$ & $-\mathbf{F}$ & $+\mathbf{F}$ \\
\hline Control & $382.4 \mathrm{Aa}$ & $137.7 \mathrm{Ba}$ & $1.64 \mathrm{Ab}$ & $1.90 \mathrm{Bb}$ & $1.56 \mathrm{Ab}$ & $1.86 \mathrm{Bb}$ & $72.04 \mathrm{Ab}$ & $84.30 \mathrm{Bc}$ & $68.47 \mathrm{Ab}$ & $82.51 \mathrm{Bc}$ \\
\hline $\mathrm{KSi}$ & $303.2 \mathrm{Ab}$ & $93.26 \mathrm{Bbc}$ & $1.81 \mathrm{Ab}$ & $2.02 \mathrm{Ab}$ & $1.72 \mathrm{Ab}$ & $1.99 \mathrm{Bb}$ & $79.22 \mathrm{Ab}$ & $88.49 \mathrm{Abc}$ & $75.97 \mathrm{Ab}$ & $87.05 \mathrm{Bbc}$ \\
\hline NaMo & 335.8 Aab & 124.5 Bab & $2.25 \mathrm{Aa}$ & $2.32 \mathrm{Aab}$ & $2.13 \mathrm{Aa}$ & $2.28 \mathrm{Aab}$ & $99.26 \mathrm{Aa}$ & 103.4 Aab & $94.46 \mathrm{Aa}$ & 101.4 Aab \\
\hline $\mathrm{KSi}+\mathrm{NaMo}$ & $283.0 \mathrm{Ab}$ & $66.61 \mathrm{Bc}$ & $2.35 \mathrm{Aa}$ & $2.57 \mathrm{Aa}$ & $2.26 \mathrm{Aa}$ & $2.54 \mathrm{Aa}$ & $104.5 \mathrm{Aa}$ & $112.8 \mathrm{Aa}$ & $101.0 \mathrm{Aa}$ & $111.7 \mathrm{Aa}$ \\
\hline MS & \multicolumn{2}{|c|}{$8,312.16^{*}$} & \multicolumn{2}{|c|}{$0.60 *$} & \multicolumn{2}{|c|}{$0.59^{*}$} & \multicolumn{2}{|c|}{$1,240.14^{*}$} & \multicolumn{2}{|c|}{$1,229.82 *$} \\
\hline $\mathrm{CV}(\%)$ & \multicolumn{2}{|c|}{10.26} & \multicolumn{2}{|c|}{5.60} & \multicolumn{2}{|c|}{5.60} & \multicolumn{2}{|c|}{5.40} & \multicolumn{2}{|c|}{5.50} \\
\hline
\end{tabular}

${ }^{\mathrm{z}}$ For each variable, means within a row followed by the same uppercase letter or means within a column followed by the lowercase same letter are not significantly different $(P=0.05)$ as determined by Tukey's test. Asterisk $(*)$ indicates significant at $P=0.05$ by $F$ test. MS $=$ mean square and $C V=$ coefficient of variation.

Table 4. Single degree-of-freedom contrasts for comparisons of the treatments potassium silicate $(\mathrm{KSi})$, sodium molybdate $(\mathrm{NaMo})$, and $\mathrm{KSi}+\mathrm{NaMo}$ on area under anthracnose progress curve (AUDPC), leaf area index $\left(\mathrm{LAI}, \mathrm{m}^{2} / \mathrm{m}^{2}\right)$, healthy leaf area index (HLAI, $\left.\mathrm{m}^{2} / \mathrm{m}^{2}\right)$, leaf area index duration (LAD, days), healthy leaf area duration (HAD, days), intercepted radiation of the healthy leaf area $\left(\mathrm{HRI}, \mathrm{MJ} / \mathrm{m}^{2}\right)$, healthy leaf area absorption $\left(\mathrm{HAA}, \mathrm{MJ} / \mathrm{m}^{2}\right)$, intercepted radiation $\left(\mathrm{RI}, \mathrm{MJ} / \mathrm{m}^{2}\right)$, radiation use efficiency (RUE, g/MJ), and grain yield (Yield, g/plant) in experiment $1^{\mathrm{z}}$

\begin{tabular}{|c|c|c|c|c|c|c|c|c|c|c|}
\hline \multirow[b]{2}{*}{ Contrasts } & \multirow[b]{2}{*}{ AUDPC } & \multicolumn{4}{|c|}{ Growth variables } & \multicolumn{4}{|c|}{ Physiological variables } & \multirow[b]{2}{*}{ Yield } \\
\hline & & LAI & HLAI & LAD & HAD & HRI & HAA & RI & RUE & \\
\hline -KSi vs. $+\mathrm{KSi}$ & $11,468.22 * *$ & $0.06 \mathrm{~ns}$ & $0.06^{*}$ & $96.95 \mathrm{~ns}$ & $108.60 \mathrm{~ns}$ & $0.24 *$ & $378.675^{*}$ & $0.81 \mathrm{~ns}$ & $0.0003 \mathrm{~ns}$ & $1.36^{*}$ \\
\hline $\begin{array}{l}\text {-NaMo vs. +NaMo } \\
\text {-KSi -NaMo vs. }\end{array}$ & $2675.75^{*}$ & $0.79 * *$ & $0.73 * *$ & $1,613.56^{* *}$ & $1,514.70 * *$ & $2.89 * *$ & $5,698.52 * *$ & $2.66 * *$ & $0.0007 \mathrm{~ns}$ & $4.91 * *$ \\
\hline$+\mathrm{KSi}+\mathrm{NaMo}$ & $21,809.50 * *$ & $1.40 * *$ & $1.42 * *$ & $2,796.85^{* *}$ & $2,868.44 * *$ & $4.50 * *$ & $8,652.14 * *$ & $4.02 * *$ & $0.029 * *$ & $76.45^{*}$ \\
\hline
\end{tabular}

${ }^{\mathrm{z}}$ Asterisks $*$ and $* *=$ significant at $P=0.05$ and 0.01 , respectively, by $F$ test; ns $=$ not significant; - and $+=$ nonsprayed and sprayed, respectively. 
variables were higher by $9.45,13.0,9.6$, and $12.6 \%$, respectively, for the plants sprayed with fungicide compared with the nonsprayed plants (Table 1) whereas, in the second, LAI, HLAI, LAD, and HAD increased by $7.8,8.8,7.5$, and $8.6 \%$, respectively, with fungicide spray (Table 2). Regardless of the experiment, LAI,
$\mathrm{LAD}$, and HAD were not affected by the KSi spray (Tables 4 and 7). HLAI was affected by KSi spray only in experiment 1 (Table 4). The LAI values increased by 29.1 and $39.0 \%$ in experiment 1 (Tables 3 and 4) and by 32.5 and $44.4 \%$ in experiment 2 (Tables 6 and 7) for plants sprayed with $\mathrm{NaMo}$ and $\mathrm{NaMo}+\mathrm{KSi}$, respec-

Table 5. Effects of potassium silicate ( $\mathrm{KSi}$ ), sodium molybdate (NaMo), $\mathrm{KSi}+\mathrm{NaMo}$, and no spray (control) applied to bean foliage alone or in combination with fungicide $\left(-\mathrm{F}\right.$ and $+\mathrm{F}$, respectively) on the physiological variables intercepted radiation of the healthy leaf area $\left(\mathrm{HRI}, \mathrm{MJ} / \mathrm{m}^{2}\right)$, healthy leaf area absorption (HAA, MJ $/ \mathrm{m}^{2}$ ), intercepted radiation (RI, MJ $/ \mathrm{m}^{2}$ ), radiation use efficiency (RUE, g/MJ), and yield (Yield, g/plant) in experiment $1^{\mathrm{z}}$

\begin{tabular}{|c|c|c|c|c|c|c|c|c|c|c|}
\hline \multirow[b]{3}{*}{ Treatments } & \multicolumn{8}{|c|}{ Physiological variables } & & \\
\hline & \multicolumn{2}{|c|}{ HRI } & \multicolumn{2}{|c|}{ HAA } & \multicolumn{2}{|c|}{ RI } & \multicolumn{2}{|c|}{ RUE } & \multicolumn{2}{|c|}{ Yield } \\
\hline & $-\mathbf{F}$ & $+\mathbf{F}$ & $-\mathbf{F}$ & $+\mathbf{F}$ & $-\mathbf{F}$ & $+\mathbf{F}$ & $-\mathbf{F}$ & $+\mathbf{F}$ & $-\mathbf{F}$ & $+\mathbf{F}$ \\
\hline Control & $8.776 \mathrm{Ab}$ & $9.58 \mathrm{Bb}$ & $380.8 \mathrm{Ab}$ & $416.9 \mathrm{Bb}$ & $9.00 \mathrm{Ab}$ & $9.67 \mathrm{Bb}$ & $0.20 \mathrm{Ab}$ & $0.44 \mathrm{Bb}$ & $6.49 \mathrm{Ac}$ & $15.44 \mathrm{Bc}$ \\
\hline $\mathrm{KSi}$ & $9.103 \mathrm{Ab}$ & $9.83 \mathrm{Bab}$ & $394.4 \mathrm{Ab}$ & $425.7 \mathrm{Bb}$ & $9.27 \mathrm{Ab}$ & $9.89 \mathrm{Bab}$ & $0.21 \mathrm{Ab}$ & $0.45 \mathrm{Bb}$ & $7.13 \mathrm{Ab}$ & 16.15 Bcb \\
\hline NaMo & $10.06 \mathrm{Aa}$ & 10.26 Aab & $438.4 \mathrm{Aa}$ & 446.4 Aab & $10.24 \mathrm{Aa}$ & 10.31 Aab & $0.18 \mathrm{Ac}$ & $0.47 \mathrm{Bb}$ & $6.83 \mathrm{Abc}$ & $17.66 \mathrm{Bb}$ \\
\hline $\mathrm{KSi}+\mathrm{NaMo}$ & 10.19 Aa & $10.62 \mathrm{Ba}$ & 445.3 Aa & $459.7 \mathrm{Aa}$ & $10.34 \mathrm{Aa}$ & $10.65 \mathrm{Aa}$ & $0.23 \mathrm{Aa}$ & $0.61 \mathrm{Ba}$ & $8.65 \mathrm{Aa}$ & $23.38 \mathrm{Ba}$ \\
\hline MS & \multicolumn{2}{|c|}{$1,982 *$} & \multicolumn{2}{|c|}{$3,931.08^{*}$} & \multicolumn{2}{|c|}{$1.82 *$} & \multicolumn{2}{|c|}{$0.013^{*}$} & \multicolumn{2}{|c|}{$30.63 *$} \\
\hline $\mathrm{CV}(\%)$ & \multicolumn{2}{|c|}{2.20} & \multicolumn{2}{|c|}{2.00} & \multicolumn{2}{|c|}{2.10} & \multicolumn{2}{|c|}{3.80} & \multicolumn{2}{|c|}{3.20} \\
\hline
\end{tabular}

${ }^{\mathrm{z}}$ For each variable, means within a row followed by the same uppercase letter or means within a column followed by the same lowercase letter are not significantly different $(P=0.05)$ as determined by Tukey's test. Asterisk $(*)$ indicates significant at $P=0.05$ by $F$ test. MS $=$ mean square and CV $=$ coefficient of variation.

Table 6. Effects of potassium silicate (KSi), sodium molybdate (NaMo), $\mathrm{KSi}+\mathrm{NaMo}$, and no spray (control) applied to bean foliage alone or in combination with fungicide ( $-\mathrm{F}$ and $+\mathrm{F}$, respectively) on the area under anthracnose progress curve (AUDPC) and on the growth variables leaf area index $\left(\mathrm{LAI}, \mathrm{m}^{2} / \mathrm{m}^{2}\right)$, healthy leaf area index (HLAI, $\mathrm{m}^{2} / \mathrm{m}^{2}$ ), leaf area index duration (LAD, days), and healthy leaf area duration (HAD, days) in experiment $2^{\mathrm{z}}$

\begin{tabular}{|c|c|c|c|c|c|c|c|c|c|c|}
\hline \multirow[b]{3}{*}{ Treatments } & & & \multicolumn{8}{|c|}{ Growth variables } \\
\hline & \multicolumn{2}{|c|}{ AUDPC } & \multicolumn{2}{|c|}{ LAI } & \multicolumn{2}{|c|}{ HLAI } & \multicolumn{2}{|c|}{ LAD } & \multicolumn{2}{|c|}{ HAD } \\
\hline & $-\mathbf{F}$ & $+\mathbf{F}$ & $-\mathbf{F}$ & $+\mathbf{F}$ & $-\mathbf{F}$ & $+\mathbf{F}$ & $-\mathbf{F}$ & $+\mathbf{F}$ & $-\mathbf{F}$ & $+\mathbf{F}$ \\
\hline Control & $73.74 \mathrm{Aa}$ & $28.05 \mathrm{Ba}$ & $1.96 \mathrm{Ab}$ & $2.07 \mathrm{Ac}$ & $1.91 \mathrm{Ab}$ & $2.04 \mathrm{Ac}$ & $54.34 \mathrm{Ab}$ & $57.92 \mathrm{Ab}$ & $52.85 \mathrm{Ab}$ & $57.23 \mathrm{Bc}$ \\
\hline $\mathrm{KSi}$ & $47.36 \mathrm{Ab}$ & $19.32 \mathrm{Bb}$ & $2.00 \mathrm{Ab}$ & $2.14 \mathrm{Ac}$ & $1.97 \mathrm{Ab}$ & $2.13 \mathrm{Ac}$ & $55.30 \mathrm{Ab}$ & $59.02 \mathrm{Ab}$ & $54.36 \mathrm{Ab}$ & $58.24 \mathrm{Ac}$ \\
\hline NaMo & $55.18 \mathrm{Ab}$ & $28.82 \mathrm{Ba}$ & $2.58 \mathrm{Aa}$ & $2.76 \mathrm{Ab}$ & $2.51 \mathrm{Aa}$ & $2.72 \mathrm{Ab}$ & $69.94 \mathrm{Aa}$ & $74.59 \mathrm{Aa}$ & $68.38 \mathrm{Aa}$ & $73.66 \mathrm{Ab}$ \\
\hline $\mathrm{KSi}+\mathrm{NaMo}$ & $37.72 \mathrm{Ab}$ & $12.26 \mathrm{Bb}$ & $2.76 \mathrm{Aa}$ & $3.06 \mathrm{Ba}$ & $2.72 \mathrm{Aa}$ & $3.05 \mathrm{Ba}$ & $76.48 \mathrm{Aa}$ & $83.76 \mathrm{Aa}$ & $75.40 \mathrm{Aa}$ & $83.34 \mathrm{Aa}$ \\
\hline MS & \multicolumn{2}{|c|}{$745.89^{*}$} & \multicolumn{2}{|c|}{$1.17^{*}$} & \multicolumn{2}{|c|}{$1.16^{*}$} & \multicolumn{2}{|c|}{$827.03 *$} & \multicolumn{2}{|c|}{$833.69 *$} \\
\hline $\mathrm{CV}(\%)$ & \multicolumn{2}{|c|}{13.79} & \multicolumn{2}{|c|}{4.40} & \multicolumn{2}{|c|}{4.10} & \multicolumn{2}{|c|}{5.20} & \multicolumn{2}{|c|}{5.10} \\
\hline
\end{tabular}

${ }^{\mathrm{z}}$ For each variable, means within a row followed by the same uppercase letter or means within a column followed by the same lowercase letter are not significantly different $(P=0.05)$ as determined by Tukey's test. Asterisk $(*)$ indicates significant at $P=0.05$ by $F$ test. MS $=$ mean square and CV $=$ coefficient of variation.

Table 7. Single degree-of-freedom contrasts for comparisons of the treatments potassium silicate (KSi), sodium molybdate (NaMo), and $\mathrm{KSi}+\mathrm{NaMo}$ on area under anthracnose progress curve (AUDPC), leaf area index (LAI, $\left.\mathrm{m}^{2} / \mathrm{m}^{2}\right)$, healthy leaf area index (HLAI, $\left.\mathrm{m}^{2} / \mathrm{m}^{2}\right)$, leaf area index duration $(\mathrm{LAD}$, days), healthy leaf area duration (HAD, days), intercepted radiation of the healthy leaf area (HRI, $\left.\mathrm{MJ} / \mathrm{m}^{2}\right)$, healthy leaf area absorption (HAA, MJ $\left./ \mathrm{m}^{2}\right)$, intercepted radiation (RI, $\mathrm{MJ} / \mathrm{m}^{2}$ ), radiation use efficiency (RUE, g/MJ), and grain yield (Yield, g/plant) on bean plants ('Pérola') in experiment $2^{\mathrm{z}}$

\begin{tabular}{|c|c|c|c|c|c|c|c|c|c|c|}
\hline \multirow[b]{2}{*}{ Contrasts } & \multirow[b]{2}{*}{ AUDPC } & \multicolumn{4}{|c|}{ Growth variables } & \multicolumn{4}{|c|}{ Physiological variables } & \multirow[b]{2}{*}{ Yield } \\
\hline & & LAI & HLAI & LAD & HAD & HRI & HAA & RI & RUE & \\
\hline -KSi vs. +KSi & $924.0^{*}$ & $0.06 \mathrm{~ns}$ & $0.009 \mathrm{~ns}$ & $3.17 \mathrm{~ns}$ & $4.75 \mathrm{~ns}$ & $0.83 \mathrm{~ns}$ & $418.6^{*}$ & $0.68 \mathrm{~ns}$ & $0.004 * *$ & $8.68 *$ \\
\hline -NaMo vs. +NaMo & $237.2 *$ & $0.79 * *$ & $1.28 * *$ & $781.01 * *$ & $765.92 * *$ & $17.0^{* *}$ & $8,744.4 * *$ & $18.1^{* *}$ & $0.003^{* *}$ & $19.07 * *$ \\
\hline$+\mathrm{KSi}+\mathrm{NaMo}$ & $2,012.4 * *$ & $1.40 * *$ & $2.39 * *$ & $1,775.60^{* *}$ & $1,775.60^{* *}$ & $23.90 * *$ & $13,665.3^{* *}$ & $102.0 * *$ & $0.013 * *$ & $59.56^{*}$ \\
\hline
\end{tabular}

${ }^{\mathrm{z}}$ Asterisks * and $* *=$ significant at $P=0.05$ and 0.01 , respectively, by $F$ test; ns $=$ not significant; - and $+=$ nonsprayed and sprayed, respectively.

Table 8. Effects of potassium silicate $(\mathrm{KSi})$, sodium molybdate $(\mathrm{NaMo}), \mathrm{KSi}+\mathrm{NaMo}$, and no spray (control) applied to bean foliage alone or in combination with fungicide ( $-\mathrm{F}$ and $+\mathrm{F}$, respectively) on the physiological variables intercepted radiation of the healthy leaf area (RHI), healthy leaf area absorption $\left(\mathrm{HAA}, \mathrm{MJ} / \mathrm{m}^{2}\right)$, intercepted radiation $\left(\mathrm{RI}, \mathrm{MJ} / \mathrm{m}^{2}\right)$, radiation use efficiency (RUE, g/MJ), and grain yield (Yield, g/plant) in experiment $2^{\mathrm{z}}$

\begin{tabular}{|c|c|c|c|c|c|c|c|c|c|c|}
\hline \multirow[b]{3}{*}{ Treatments } & \multicolumn{8}{|c|}{ Physiological variables } & & \\
\hline & \multicolumn{2}{|c|}{ IRH } & \multicolumn{2}{|c|}{ HAA } & \multicolumn{2}{|c|}{ IR } & \multicolumn{2}{|c|}{ RUE } & \multicolumn{2}{|c|}{ Yield } \\
\hline & $-\mathbf{F}$ & $+\mathbf{F}$ & $-\mathbf{F}$ & $+\mathbf{F}$ & $-\mathbf{F}$ & $+\mathbf{F}$ & $-\mathbf{F}$ & $+\mathbf{F}$ & $-\mathbf{F}$ & $+\mathbf{F}$ \\
\hline Control & $16.47 \mathrm{Ab}$ & $16.75 \mathrm{Ab}$ & $421.6 \mathrm{Ab}$ & $429.4 \mathrm{Ab}$ & $15.48 \mathrm{Ab}$ & $15.62 \mathrm{Ab}$ & $0.18 \mathrm{Aa}$ & $0.38 \mathrm{Bc}$ & $6.5 \mathrm{Ab}$ & $13.16 \mathrm{Bd}$ \\
\hline $\mathrm{KSi}$ & $16.73 \mathrm{Ab}$ & $17.54 \mathrm{Bb}$ & $428.2 \mathrm{Ab}$ & $446.3 \mathrm{Ab}$ & $15.67 \mathrm{Ab}$ & $16.39 \mathrm{Bb}$ & $0.20 \mathrm{Aa}$ & $0.44 \mathrm{Bb}$ & 7.35 Aab & $16.41 \mathrm{Bc}$ \\
\hline NaMo & $18.64 \mathrm{Aa}$ & $19.33 \mathrm{Aa}$ & $471.2 \mathrm{Aa}$ & $487.8 \mathrm{Aa}$ & $17.68 \mathrm{Aa}$ & $18.35 \mathrm{Aa}$ & $0.17 \mathrm{Aa}$ & $0.46 \mathrm{Bb}$ & $6.64 \mathrm{Aab}$ & $18.77 \mathrm{Bb}$ \\
\hline $\mathrm{KSi}+\mathrm{NaMo}$ & $18.81 \mathrm{Aa}$ & $20.06 \mathrm{Ba}$ & $479.4 \mathrm{Aa}$ & $506.5 \mathrm{Ba}$ & $17.89 \mathrm{Aa}$ & $19.10 \mathrm{Ba}$ & $0.18 \mathrm{Aa}$ & $0.52 \mathrm{Ba}$ & $7.36 \mathrm{Aa}$ & $21.88 \mathrm{Ba}$ \\
\hline MS & \multicolumn{2}{|c|}{$11.43 *$} & \multicolumn{2}{|c|}{$6,337.90^{*}$} & \multicolumn{2}{|c|}{$12.58^{*}$} & \multicolumn{2}{|c|}{$0.004^{*}$} & \multicolumn{2}{|c|}{$20.37 *$} \\
\hline $\mathrm{CV}(\%)$ & \multicolumn{2}{|c|}{2.80} & \multicolumn{2}{|c|}{2.80} & \multicolumn{2}{|c|}{3.00} & \multicolumn{2}{|c|}{4.30} & \multicolumn{2}{|c|}{3.90} \\
\hline
\end{tabular}

${ }^{\mathrm{z}}$ For each variable, means within a row followed by the same uppercase letter or means within a column followed by the same lowercase letter are not significantly different $(P=0.05)$ as determined by Tukey's test. Asterisk $(*)$ indicates significant at $P=0.05$ by $F$ test. MS $=$ mean square and CV $=$ coefficient of variation. 
tively, compared with the nonsprayed plants. HLAI increased by $8.5,29.0$, and $40.4 \%$ with the $\mathrm{KSi}$, NaMo, and $\mathrm{NaMo}+\mathrm{KSi}$ sprays, respectively, in experiment 1 (Tables 3 and 4) and by 32.4 and $46.1 \%$ for the plants sprayed with $\mathrm{NaMo}$ and $\mathrm{NaMo}+\mathrm{KSi}$, respectively, compared with the nonsprayed plants (Tables 6 and 7). LAD increased by 29.6 and $39.0 \%$ and HAD by 29.7 and $41.0 \%$ for the plants sprayed with $\mathrm{NaMo}$ and $\mathrm{NaMo}+\mathrm{KSi}$, respectively, in experiment 1 (Tables 3 and 4) and LAD by 28.8 and $42.7 \%$ and HAD by 29.0 and $44.2 \%$ for the plants sprayed with $\mathrm{NaMo}$ and $\mathrm{NaMo}+\mathrm{KSi}$, respectively, in experiment 2 (Tables 6 and 7).

Variables related to bean physiology. Fungicide applications increased all the variables related to bean physiology. RI and HRI increased by 4.3 and $5.7 \%$, respectively, in experiment 1 (Table 1) and by 4.1 and $4.30 \%$, respectively, in experiment 2 (Table 2) and for the plants treated with fungicide compared with the nonsprayed plants. RI was not affected by KSi in experiments 1 and 2 (Tables $4,5,7$, and 8), while the HRI was not affected by KSi only in experiment 2 (Tables 7 and 8). RI significantly increased by 10.1 and $12.4 \%$ in experiment 1 (Tables 4 and 5) and by 15.9 and $19.0 \%$ in experiment 2 (Tables 7 and 8) for the plants sprayed with NaMo and $\mathrm{NaMo}+\mathrm{KSi}$, respectively. HRI significantly increased by 3.1 , 10.7 , and $13.4 \%$ in experiment 1 for the plants sprayed with Ksi, $\mathrm{NaMo}$, and $\mathrm{NaMo}+\mathrm{Ksi}$, respectively (Tables 4 and 5) and by 14.3 and $17.0 \%$ in experiment 2 for the plants sprayed with NaMo and $\mathrm{NaMo}+\mathrm{KSi}$, respectively (Tables 7 and 8). HAA and RUE significantly increased by 5.4 and $133.3 \%$ in experiment 1 , respectively, and by 3.9 and $150.0 \%$, respectively, with the fungicide treatment (Table 1). HAA significantly increased by 2.8 , 10.9, and $13.5 \%$ in experiment 1 (Tables 4 and 5) and by 2.8, 12.7, and $15.9 \%$ in experiment 2 (Tables 7 and 8) for the plants sprayed with $\mathrm{KSi}, \mathrm{NaMo}$, and $\mathrm{NaMo}+\mathrm{KSi}$, respectively. In experiment 1 , RUE was not affected by the KSi spray (Tables 4 and 5) whereas, in experiment 2, RUE significantly increased by $14.3,12.5$, and $25.0 \%$ for the plants sprayed with $\mathrm{KSi}, \mathrm{NaMo}$, and $\mathrm{NaMo}+\mathrm{KSi}$, respectively (Tables 7 and 8). RUE significantly increased by 1.6 and $31.3 \%$ for the plants sprayed with $\mathrm{NaMo}$ and $\mathrm{NaMo}+\mathrm{KSi}$, respectively, in experiment 1 (Tables 4 and 5).

\section{Discussion}

$\mathrm{Si}$, either applied to the soil or as a foliar spray, reduces the intensity of diseases of economic importance in crops such as barley, corn, cucumber, grape, rye, rice, soybean, and strawberry $(5,31,32)$. There are also a few reports showing the involvement of Mo in reducing the intensity of diseases on bean and tomato $(7,15,24)$. To the best of our knowledge, however, no study on the bean-C. lindemuthianum pathosystem to date has investigated whether $\mathrm{Si}$ and $\mathrm{Mo}$ and their combination could increase host resistance to anthracnose.

The present study shows that foliar application of KSi in combination with $\mathrm{NaMo}$ or in combination with a foliar fungicide could be an effective strategy for the management of anthracnose, resulting in greater yield. The foliar spray of $\mathrm{KSi}$ in combination with NaMo reduced the AUDPC. Similarly, an application of KSi alone reduced anthracnose symptoms and, consequently, AUDPC, resulting in greater yield. Foliar applications of KSi have been used successfully in such crops as bean, which has a poor capacity to take up Si from the soil solution and translocate it to the shoots (21). Moraes et al. (25) reported that a foliar spray of sodium silicate to bean plants decreased the AUDPC by $62.4 \%$ whereas a $\mathrm{KSi}$ application reduced angular leaf spot severity on bean plants by an average of $36 \%$ (32). In the present study, foliar application of $\mathrm{KSi}$ resulted in satisfactory anthracnose control, possibly due to the formation of a physical barrier as a result of the deposition of Si on the leaf surface or the osmotic effect of silicate sprayed onto the leaves. Anthracnose severity on plants from the control treatment reached 20.5 and $7.9 \%$, respectively, in experiments 1 and 2 . These values are considered quite high because the highest severity value in the diagrammatic scale used is $24 \%$. Considering that the same cultivar was used in experiments 1 and 2 and plants were inocu- lated with the same isolate of $C$. lindemuthianum and at the same conidial concentration, the difference in the amount of disease between experiments was exclusively due to the environmental conditions. In Brazil, anthracnose is more severe on plants grown during low-temperature conditions (37), as was the case for experiment 1 that was carried out during the fall.

The application of NaMo decreased AUDPC, possibly because of its direct effect on $C$. lindemuthianum, thus increasing yield. As a heavy metal, Mo causes the denaturation of proteins and negatively affects lytic enzymes and nonselective toxins produced by pathogens (11), including $C$. lindemuthianum. Thus, contact of the C. lindemuthianum conidia produced from multiple cycles of the pathogen during the crop season with the NaMo solution could had affected their viability, growth, and further host tissue penetration, therefore decreasing anthracnose severity. It is also plausible that Mo may mediate some mechanisms of host defense against anthracnose, which merits further investigation.

Fungicide spray reduced the impact of anthracnose on yield and contributed to greater LAI, HLAI, LAD, HAD, HRI, and HAA and, consequently, was directly linked to better plant growth. A high yield can also be linked to the positive relationship of Mo with the physiological and host growth variables evaluated in the present study. The values for the physiological variables HAA, HRI, RI, and RUE, as well as those related to host growth, LAI, HLAI, LAD, and HAD, were greatly enhanced after fungicide spraying. Within this context, fungicide provided substantial control of anthracnose, sufficient to account for the improved plant growth and yield. Foliar application of KSi had no significant effect on the variables LAI, LAD, and HAD because bean plants are not able to uptake much Si through foliage (34). Thus, it is likely that $\mathrm{KSi}$ is related to the reduction in anthracnose severity by its direct effect on the pathogen's development and not on bean growth. Bowen et al. (3) reported that the layers of KSi covering the cuticle of vine leaves prevented both germination and the penetration of ascospores of Uncinula necator; in contrast, the fungus grew without being impeded on the leaf areas that were not covered. Foliar application of KSi mainly increased yield through the decrease in anthracnose severity, corroborating the results of Rodrigues et al. (32), who obtained an increase in bean yield from 30 to $43 \%$ with foliar application of KSi for angular leaf spot.

The values for the variables LAI, HLAI, LAD, HAD, RI, HRI, HAA, and RUE were higher on the plants sprayed with NaMo, reflecting a positive effect of this micronutrient on growth and yield. A plausible explanation for a gain in yield due to NaMo spraying may be the role played by Mo in the activity of the enzymes NR and nitrogenase, both involved in nitrogen fixation (6). Jesus Júnior et al. (15) reported an increase of approximately $17 \%$ in seed yield upon NaMo spraying onto bean plants with angular leaf spot symptoms. The increase in yield was attributed to the reduction in disease severity and to the involvement of Mo in nitrogen metabolism, helping to increase the plant dry weight $(36,38)$.

The results of the present study evoke a novel possibility of using foliar application of $\mathrm{KSi}$ in association with NaMo to reduce anthracnose severity on bean plants and, consequently, achieve greater gains in yield due to improved plant growth.

\section{Literature Cited}

1. Bassanezi, R. B., Amorim, L., and Bergamin Filho, A. 2001. Eficiência fotossintética de folhas de feijoeiro infectadas com o vírus do mosaico-emdesenho, Uromyces appendiculatus e Phaeoisariopsis griseola. Summa Phytopathol. 27:5-11.

2. Bergamin Filho, A., Carneiro, S. M. T. P., Godoy, C. V., Amorim, L., Berger, R. D., and Hau, B. 1997. Angular leaf spot of Phaseolus beans: relationships between disease, healthy leaf area, and yield. Phytopathology 87:506-515.

3. Bowen, P. J, Menzies, J., and Ehret, D. 1992. Soluble silicon sprays inhibit powdery mildew development on grape leaves. J. Am. Soc. Hortic. Sci. 117:906-912

4. Carver, T. L. W., Zeyen, R. J., and Ahlstrand, G. G. 1987. The relationship between insoluble silicon and success or failure of attempted primary penetration by powdery mildew (Erysiphe graminis) germlings on barley. Physiol. Mol. Plant Pathol. 31:133-148. 
5. Datnoff, L. E., Rodrigues, F. A., and Seebold, K. W. 2007. Silicon and plant disease. Pages 233-246 in: Mineral Nutrition and Plant Disease. L. E. Datnoff, W. H. Elmer, and D. M. Huber, eds. American Phytopathological Society, St Paul, MN.

6. Dechen, A. R., Haag, H. P., and Carmello, Q. A. C. 1991. Funções de Micronutrientes nas Plantas. Pages 65-78 in: Micronutrientes na Agricultura. M. E. Ferreira and M. C. P. Cruz, eds. POTAFOS/CNPq, Piracicaba, Brazil.

7. Dutta, B. K., and Bremmer, E. 1981. Trace elements as plant chemo therapeutants to control Verticillium wilt. Z. Pflanzenkrankh. Pflanzenschutz 88:405-412.

8. Epstein, E. 1999. Silicon. Annu. Rev. Plant Physiol. Plant Mol. Biol. 50:641-64.

9. Fauteux, F., Remus-Borel, W., Menzies, J. G., and Bélanger, R. R. 2005. Silicon and plant disease resistance against pathogenic fungi. FEMS Microbiol. Lett. 249:1-6.

10. Godoy, C. V., Carneiro, S. M., Lamauti, M. T., Pria, M. D., Amorim, L., Berger, R. D., and Filho, A. B. 1997. Diagrammatic scales for bean diseases: development and validation. Z. Pflanzenkrankh. Pflanzenschutz 104:336-345

11. Graham, R. D., and Stangouli, J. C. R. 2007. Molybdenum and plant disease. Pages 203-205 in: Mineral Nutrition and Plant Disease. L. E. Datnoff, W. H. Elmer, and D. M. Huber eds. American Phytopathological Society, St Paul, MN

12. Gupta, U. C., and Lipsett, J. 1981. Molybdenum in soil, plant and animals. Adv. Agron. 34:73-115.

13. Halsall, D. M. 1977. Effects of certain cations on the formation and infectivity of Phytophthora zoospores: II. Effects of copper, boron, cobalt, manganese, molybdenum and zinc ions. Can. J. Microbiol. 23:1002-1010.

14. Haque, M. S., and Mukhopadhyaya, M. C. 1983. Influence of some micronutrients on Rotylenchus reniformis. Indian J. Nematol. 13:115-116.

15. Jesus Júnior, W. C., Vale, F. X. R., Coelho, R. R., Hau, B., Zambolim, L., and Berger, R. D. 2004. Management of angular leaf spot in common bean (Phaseolus vulgaris L.) with molybdenum and fungicide. Agron. J. 96:665670

16. Johnson, K. B. 1987. Defoliation disease and growth: A reply. Phytopathology 77:1495-1497.

17. Kaiser, B., Gridley, K., Brady, J. N., Phillips, T., and Tyerman, S. D. 2005. The role of molybdenum in agricultural plant production. Ann. Bot. 96:745756.

18. Kim, S. G., Kim, K. W., Park, E. W., and Choi, D. 2002. Silicon-induced cell wall fortification of rice leaves, a possible cellular mechanism of enhanced host resistance to blast. Phytopathology 92:1095-1103.

19. Liang, Y. C., Hua, H., Zhu, Y.G., Zhang, J., Cheng, C., and Romheld, V. 2006. Importance of plant species and external silicon concentration to active silicon uptake and transport. New Phytol. 172:63-72.

20. Lopes, D. B., and Berger, R. D. 2001. The effects of rust and anthracnose on the photosynthetic competence of diseased bean leaves. Phytopathology 91:212-220.

21. Ma, J. F., Miyakey, Y., and Takahashi, E. 2001. Silicon as a beneficial element for crop plants. Pages 17-39 in: Silicon on Agriculture. L. E. Datnoff, G. H. Snyder, and G. H. Korndörfer, eds. Elsevier Science, Amsterdam.

22. Marschner, H. 1988. Mineral Nutrition of Higher Plants, 2nd ed. Academic
Press, San Diego, CA

23. Menzies, J. P., Bowen, D. L., and Glass, A. D. M. 1992. Foliar applications of potassium silicate reduce severity of powdery mildew on cucumber muskmelon, and zucchini squash. J. Am. Soc. Hortic. Sci. 117:902-905.

24. Miller, V. R., and Becker, Z. E. 1983. The role of microelements in cotton resistance to Verticillium wilt. Sel'sk. Biol. 11:54-56.

25. Moraes, S. R. G., Pozza, E. A., Alves, E., Pozza, A. A. A., Carvalho, J. G., Lima, P. H., and Botelho, A. O. 2005. Efeito de fontes de silício na incidência e na severidade da antracnose do feijoeiro. Fitopatol. Bras. 31:69-75.

26. Nunes, W. M. C., and Bergamin Filho, A. 1996. Avaliação dos danos causados pela antracnose (Colletotrichum lindemuthianum) do feijoeiro. Fitopatol. Bras. 21:436-442.

27. Oliveira, S.F. 2003. Novos fungicidas e programas de pulverização para o controle da antracnose e da mancha angular do feijoeiro. Summa Phytopathol. 29:45-48.

28. Pengelly, B. C., Blamey, F. P. C., and Muchow, R. C. 1999. Radiation interception and the accumulation of biomass and nitrogen by soybean and three tropical annual forage legumes. Field Crop Res. 63:99-112.

29. Rava, C. A., Purchio, A. F., and Sartorato, A. 1994. Caracterização de patótipos de Colletotrichum lindemuthianum que ocorrem em algumas regiões produtoras de feijoeiro comum. Fitopatol. Bras. 19:167-172.

30. Rodrigues, F. A., Benhamou, N., Datnoff, L. E., Jones, J. B., and Bélanger, R. R. 2003. Ultrastructural and cytochemical aspects of silicon mediated rice blast resistance. Phytopathology 93:535-546.

31. Rodrigues, F. A., Duarte, H. S. S., Domiciano, G. P., Souza, C. A., Korndörfer, G. H., and Zambolim, L. 2009. Foliar application of potassium silicate reduces the intensity of soybean rust. Australas. Plant Pathol. 38:366372.

32. Rodrigues, F. A., Duarte, H. S. S., Rezende, D. C., Wordell Filho, J. A Korndörfer, G. H., and Zambolim, L. 2010. Foliar spray of potassium silicate on the control of angular leaf spot on beans. J. Plant Nutr. 33:2082 2093.

33. Rodrigues, F. A., Jurick, W. M., Datnoff, L. E., Jones, J. B., and Rollins, J. A. 2005. Silicon influences cytological and molecular events in compatible rice-Magnaporthe grisea interaction. Physiol. Mol. Plant Pathol. 66:144 159.

34. Shaner, G., and Finney, R. E. 1977. The effects of nitrogen fertilization on the expression of slow-mildewing in knox wheat. Phytopathology 67:1051 1055.

35. Sinclair, T. R., Muchow, R. C. 1999. Radiation use efficiency. Adv. Agron. 65:215-265.

36. Taiz, L., and Zeiger, E. 1998. Plant Physiology. Sinauer Associates, Sunderland, MA.

37. Vieira C. 1988. Doenças e Pragas do Feijoeiro, 2nd ed. Imprensa Universitária, Viçosa, MG, Brazil.

38. Vieira, C., Nogueira, A. O., and Araújo, A. 1992. Adubação nitrogenada e molíbdica na cultura do feijão. Rev. Agríc. 67:117-124.

39. Waggoner, P. E., and Berger, R. D. 1987. Defoliation, disease, and growth Phytopathology 77:393-398.

40. Watson, D. J. 1954. Comparative physiological studies on the growth of field crops. I. Variation in net assimilation rate and leaf area between species and varieties, and within and between years. Ann. Bot. 11:41-76. 